\title{
Contactless Electric Igniter for Vehicle to Lower Exhaust Emission and Fuel Consumption
}

\author{
Chih-Lung Shen ${ }^{1}$ and Jye-Chau $\mathrm{Su}^{2}$ \\ ${ }^{1}$ Department of Electronic Engineering, National Kaohsiung First University of Science and Technology, Yanchao, \\ Kaohsiung 824, Taiwan \\ ${ }^{2}$ Graduate Institute of Engineering Science and Technology, National Kaohsiung First University of Science and Technology, Yanchao, \\ Kaohsiung 824, Taiwan \\ Correspondence should be addressed to Chih-Lung Shen; clshen@ccms.nkfust.edu.tw
}

Received 31 August 2013; Accepted 6 December 2013; Published 5 February 2014

Academic Editors: H. Aras and K. Feng

Copyright (C) 2014 C.-L. Shen and J.-C. Su. This is an open access article distributed under the Creative Commons Attribution License, which permits unrestricted use, distribution, and reproduction in any medium, provided the original work is properly cited.

An electric igniter for engine/hybrid vehicles is presented. The igniter comprises a flyback converter, a voltage-stacked capacitor, a PIC-based controller, a differential voltage detector, and an ignition coil, of which structure is non-contact type. Since the electric igniter adopts a capacitor to accumulate energy for engine ignition instead of traditional contacttype approach, it enhances the igniting performance of a spark plug effectively. As a result, combustion efficiency is promoted, fuel consumption is saved, and exhaust emission is reduced. The igniter not only is good for fuel efficiency but also can reduce HC and CO emission significantly, which therefore is an environmentally friendly product. The control core of the igniter is implemented on a single chip, which lowers discrete component count, reduces system volume, and increases reliability. In addition, the ignition timing can be programmed so that a timing regulator can be removed from the proposed system, simplifying its structure. To verify the feasibility and functionality of the igniter, key waveforms are measured and real-car experiments are performed as well.

\section{Introduction}

Vehicle ignition system can be briefly classified as breaker point ignition system, transistorized ignition system, and capacitor discharge ignition system, of which structures and ignition mechanisms are different from each other [1-5]. However, in common, ignition timing is determined by speed signal generator for all the ignition systems. The speed signal generator mainly consists of a permanent magnet, an inductive coil, and a rotor so as to sense vehicle speed and generate ignition signal. Nevertheless, the speed signal generator cannot accurately produce optimal timing signal and its output voltage is variant. A higher output voltage occurs while in the period of low speed and a lower output voltage while in the period of high speed. It leads to over energy on spark plug in low speed, resulting in energy waste, and also leads to inadequate energy supply in high speed, resulting in knocking.

This paper proposes an engine igniter derived from a flyback-type converter to improve the characteristics of traditional capacitor discharge igniter. The proposed igniter is contactless and powered by battery. With the advantages of microprocessor-based controllers [6-16], the control core of the proposed igniter is designed and implemented on a single chip PIC18F4520. Therefore, the ignition timing is programmable so as to accommodate different vehicle velocities to achieve optimal igniting. Thus, engine can generate the most effective output power and save fuel consumptions significantly. In the igniter, a high-frequency switching flyback converter [17-22] is embedded, which boosts the battery voltage and then accumulates energy on a capacitor. After trigging, the energy stored in the capacitor will be released 


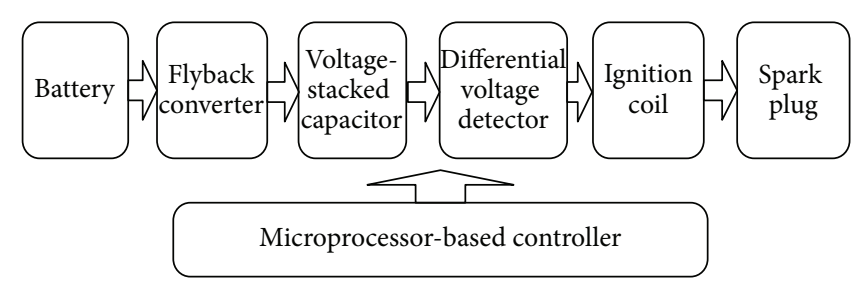

FIgURE 1: A block diagram to illustrate the structure of the proposed electronic ignition system.

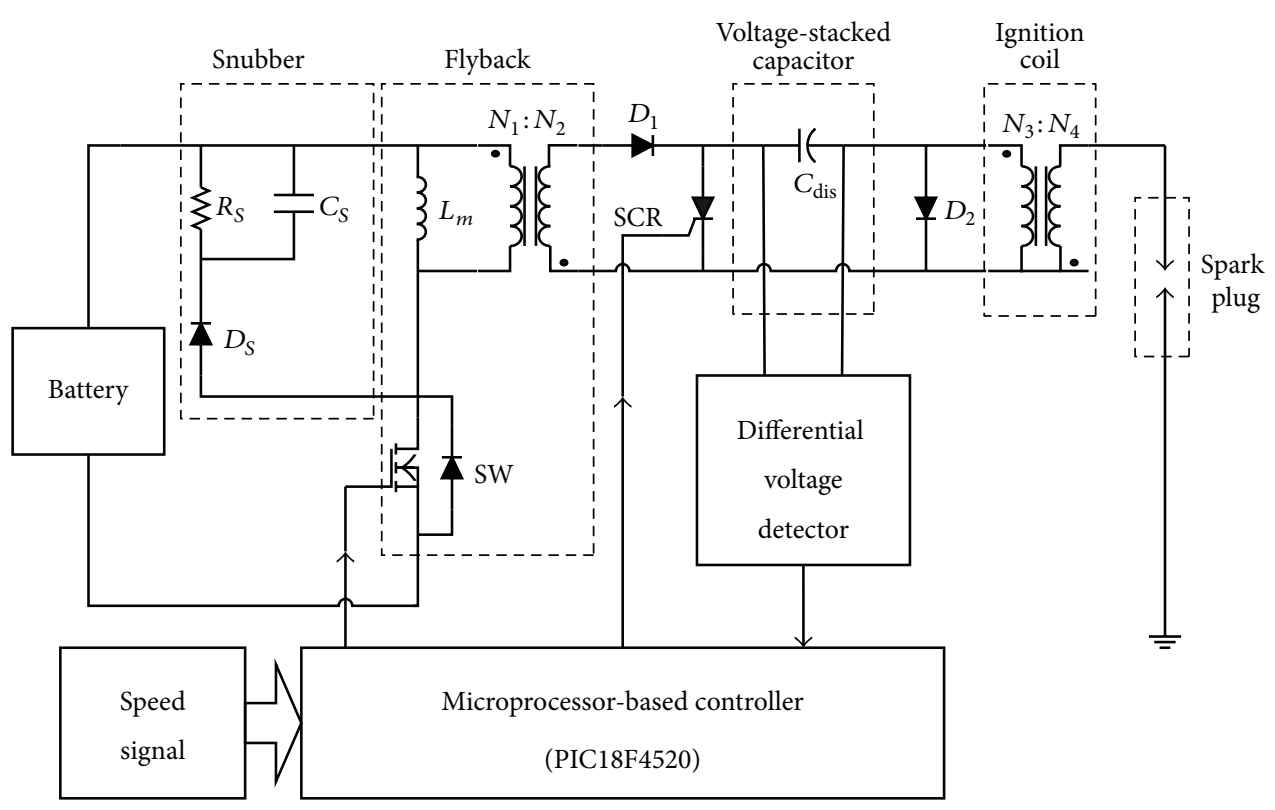

FIGURE 2: The main circuitry of the proposed igniter.

through a high turns-ratio transformer to ignite spark plug. With the mentioned ignition mechanism, the proposed electric igniter has the following advantages: slowing plug aging, having higher stability for engine operation, having simple structure, being a cost-effective product, improving combustion efficiency, lowering exhaust emission, and saving fuel consumption.

\section{System Architecture}

The block diagram of the proposed capacitor discharge ignition system for engine/hybrid vehicles is shown in Figure 1, which mainly includes a flyback converter, a voltage-stacked capacitor, a microprocessor-based controller, a differential voltage detection circuit, an ignition coil, and a spark plug. The main circuit is shown in Figure 2. The flyback converter is in charge of boosting the battery voltage by means of high-frequency switching and PWM controlling and then continuously stacks up the voltage on the capacitor $C_{\text {dis }}$ until a voltage level for igniting is reached. The voltage across the voltage-stacked capacitor is detected by the differential voltage detector. After receiving a speed signal, the controller will generate a corresponding trigging signal to turn on the silicon-controlled rectifier (SCR) such that the energy stored in the capacitor $C_{\text {dis }}$ is discharged to spark plug via the ignition coil. The ignition coil is a high turns-ratio pulse transformer, which upgrades the capacitor voltage to around $15 \mathrm{kV}$ to ignite spark plug.

For achieving maximum horsepower output and to avoid knocking, ignition timing has to be controlled exactly. An illustration is shown in Figure 3, which represents the relationship between cylinder pressure and crankshaft position under different igniting conditions. Figure 3 reveals that optimal ignition occurs while engine is ignited at the moment the crankshaft angle is 10 degrees after top dead point. A late ignition or a missing ignition results in lower cylinder pressure, that is, which will lead to more fuel consumption and exhausted gas emission. In Figure 3, even though a premature ignition gains higher cylinder pressure, knocking phenomenon appears. This knocking is in danger of car driving. Therefore, in order to let the engine combustion chamber obtain maximum efficiency, it needs to launch a plug sparkle for the engine after the top dead point of a 10-degree angle. For the optimal 10-degree igniting, a corresponding igniting sequence should be determined instantaneously during various engine speeds. In this paper, by means of software programming on a microprocessor-based controller and with the detection of engine speed, it can be easily achieved. The flowchart of the software programming is shown in Figure 4. 


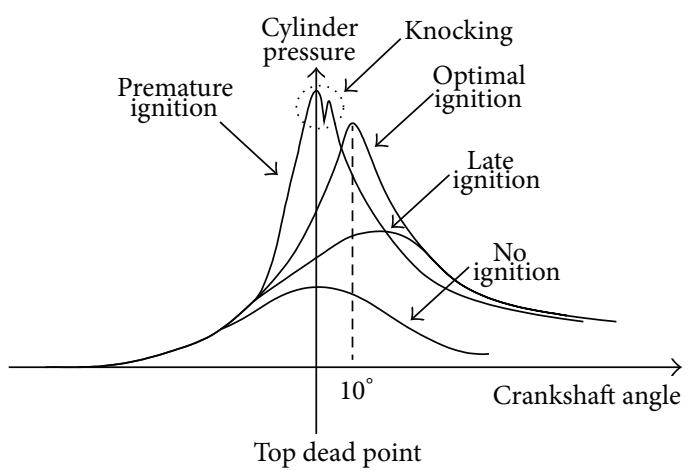

FIGURE 3: The relationship between cylinder pressure and crankshaft position.

\section{Operation Principle}

The structure of the proposed engine igniter is derived from a flyback converter. By means of PWM controlling and highfrequency switching, the flyback in the igniter delivers battery energy to voltage-stacked capacitor to accumulate energy and voltage in the capacitor. Thus, the main circuit shown in Figure 2 can be simplified as in Figure 5, which is useful to realize the operation of the igniter. The simplified circuit can operate in either CCM (continuous conduction mode) or DCM (discontinuous conduction mode). In this paper, DCM operation is considered.

According to the control for the active switch SW and SCR, the operation principle of the igniter can be divided into seven modes during each ignition cycle, which is described mode by mode in the following.

Mode 1. As shown in Figure 6(a), the active switch turns on and the battery supplies the magnetizing inductor $L_{m}$. The current of the inductor increases linearly. Meanwhile, the capacitor $C_{s}$ in the snubber discharges into the resistor $R_{s}$.

Mode 2. The capacitor $C_{s}$ discharges energy to the end but the switch SW still stays in on state. The battery continuously stores energy to inductor $L_{m}$. The equivalent is shown in Figure 6(b).

Mode 3. When SW turns off, this mode starts, as shown in Figure 6(c). The voltage across the inductance $L_{m}$ is reversed. The diodes $D_{1}$ and $D_{2}$ turn on, and the $C_{\text {dis }}$ starts to store energy. The leakage inductance energy of the high-frequency transformer is released to the $C_{s}$ by way of $D_{s}$. As the current following through leakage inductance drops to zero, this mode ends.

Mode 4. Although the leakage inductance energy is released completely, the magnetizing inductance $L_{m}$ continues to charge capacitor $C_{\text {dis }}$. This mode is illustrated in Figure 6(d). The energy stored in the capacitor $C_{\text {dis }}$ is accumulated successively by a sequence of PWM signals to control the active switch SW. That is, the mode 1 to mode 4 will repeat until the voltage across $C_{\text {dis }}$ approaches $200 \mathrm{~V}$ enough to ignite. While the $200 \mathrm{~V}$ is reached, operation of the igniter enters into the next mode.

Mode 5. As shown in Figure 6(e), the capacitor $C_{\text {dis }}$ is standing by for igniting. This mode ends as the SCR is trigged.

Mode 6. After the microprocessor controller receives speed signal, the controller determines optimal firing timing for the SCR. Then, the SCR is closed and the voltage across capacitor $C_{\text {dis }}$ is boosted by the ignition coil to a much higher voltage. At this time, the spark plug is ignited to flashover. The equivalent circuit is presented in Figure 6(f).

Mode 7. The energy stored in the leakage inductance and the magnetizing inductance of the ignition transformer is lasting to release, as shown in Figure 6(g). When SW starts conducting again at the end of mode 7 , the operation of the igniter over an igniting cycle is completed.

In design consideration, assume that the turns-ratio $n$ of the transformer in the flyback converter is $N_{1} / N_{2}$, the switching period of the SW is $T_{s}$, and duty ratio of PWM is $D$. The inductance for boundary conduction operation, $L_{m B}$, can be determined by

$$
L_{m B}=\frac{n^{2} \cdot V_{o}}{2 \cdot I_{o}} \cdot(1-D)^{2} \cdot T_{s}
$$

where $V_{o}$ is the output voltage and $I_{o}$ represents the average output current.

If the flyback converter is operated in DCM, the value of the magnetizing inductance $L_{m}$ must be less than $L_{m B}$. The input average current $I_{s}$ is thus calculated as

$$
I_{s}=\frac{1}{2} \frac{V_{\text {battery }}}{L_{m}} D^{2} T_{s}
$$

in which $V_{\text {battery }}$ stands for the input dc voltage. The average input power can be found by

$$
P_{s}=V_{\text {battery }} I_{s}=\frac{1}{2} \frac{V_{\text {battery }}^{2}}{L_{m}} D^{2} T_{s} .
$$

That is,

$$
L_{m}=\frac{1}{2} \frac{V_{\text {battery }}^{2} \cdot \eta}{P_{o}} D^{2} T_{s},
$$

where $\eta$ expresses the efficiency of the flyback and $P_{o}$ denotes its output power.

\section{Simulated and Experimental Results}

To verify the feasibility and the functionality of the proposed electronic ignition system, a prototype is constructed and then simulations and practical measurements are carried out.

In the prototype, the battery voltage is $48 \mathrm{~V}$ for hybrid electric vehicles and a stacked voltage across $C_{\text {dis }}$ for igniting is designed as $200 \mathrm{~V}$. Figure 7 shows the measured voltage waveform of the voltage-stacked capacitor, from which it 


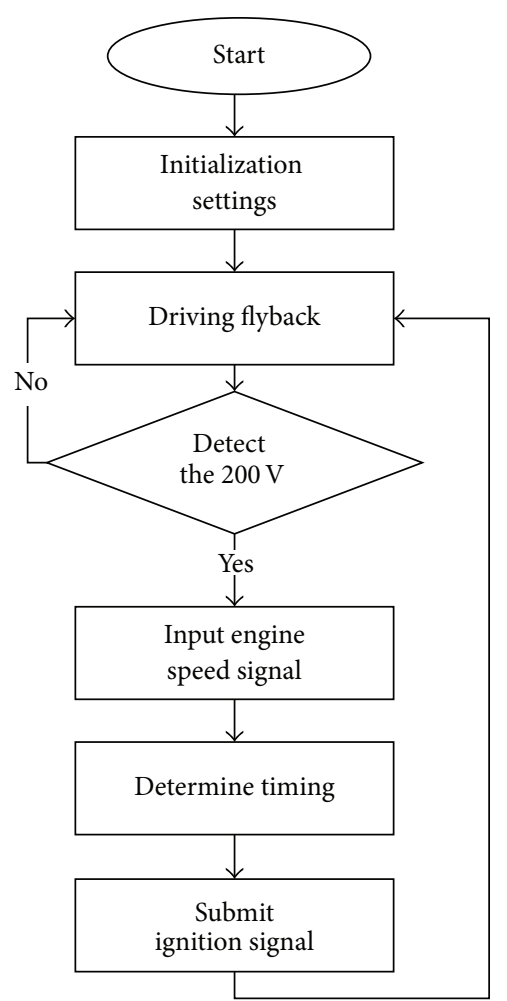

FIGURE 4: The flowchart of the software programming.

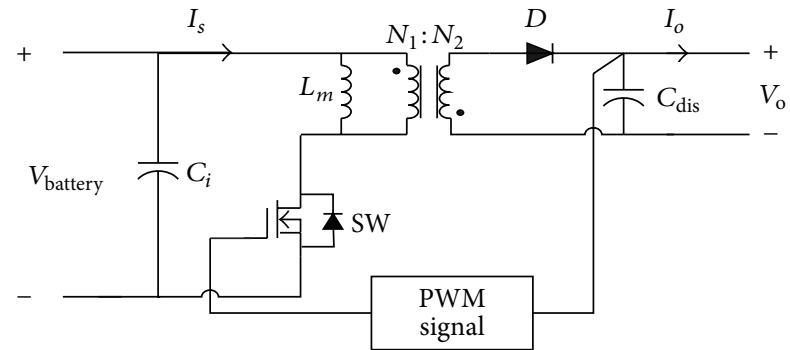

FIgURE 5: A simplified circuit of the igniter.

can be found that before igniting, $200 \mathrm{~V}$ can be reached by the flyback. In addition, the rising time of the voltage is just only $5 \mathrm{~ms}$. Figure 8 is the practical measurement of the voltage supplying to spark plug, from which it can be observed that igniting frequency is stable under fixed speed. Figure 9(a) shows the voltage waveforms measured from speed signal generator and ignition coil primary of traditional igniter at $1600 \mathrm{rpm}$, while Figure 9(b) is measured from the proposed igniter. Figure 9 reveals that at $1600 \mathrm{rpm}$, even though the traditional igniter meets igniting timing, the following oscillations will degrade combustion efficiency. At $2200 \mathrm{rpm}$, related measurements are shown in Figure 10. It can be seen that in Figure 10(a) a faster igniting timing cannot be achieved by the traditional one and following oscillation still occurs. On the contrary, in Figure 10(b), the proposed electric igniter not only accomplishes faster timing to complete optimal igniting but also has no oscillation.
To demonstrate that the proposed igniter can lead to the reduction of exhaust emission and saving fuel consumption significantly, real-car test is accomplished. Table 1 is the exhaust emission comparison between the use of traditional igniter and the proposed igniter at $1500 \mathrm{rpm}$, which are measured by an electric gas analyzer. Meanwhile, physical fuel consumption comparison is shown in Table 2. From Table 1, it can be found that with the use of the proposed igniter the exhaust emissions of $\mathrm{HC}$ and $\mathrm{CO}$ can be reduced significantly. Table 2 demonstrates that average fuel consumption is saved by $9.252 \%$.

\section{Conclusions}

In this paper an electric igniter derived from flyback converter is proposed, of which igniting timing is programmed by a microprocessor-based controller. According to the speed of vehicle, the controller can determine an optimal timing to ignite so as to improve combustions efficiency, reduce fuel consumption and lower exhaust gas pollution. The structure of the electric igniter is simple and can be powered by the vehicle battery directly. Thus, it is cost-effective and easy to install. In addition, unlike traditional igniter, the proposed igniter has no electric contact so that it can overcome the demerits such as electrode wearing, plug aging, and wrong igniting timing. In this paper, practical measurements and real-car test have verified that the proposed igniter gains higher stability for engine moving, lowers fuel consumption, and reduces exhaust gas emission effectively. That is, it is an environmentally friendly product. 


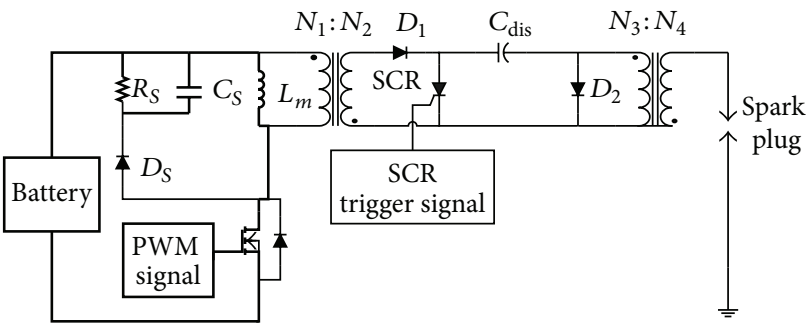

(a)

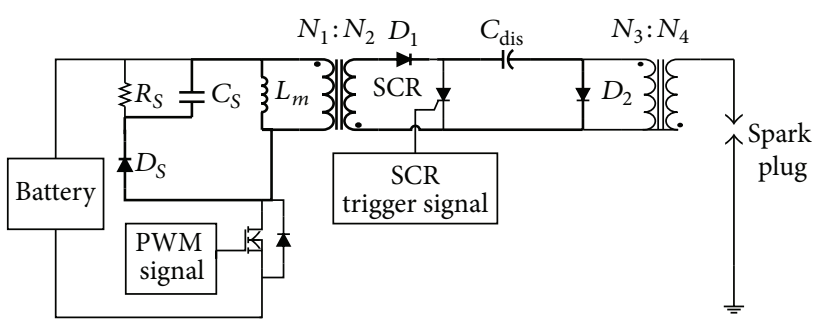

(c)

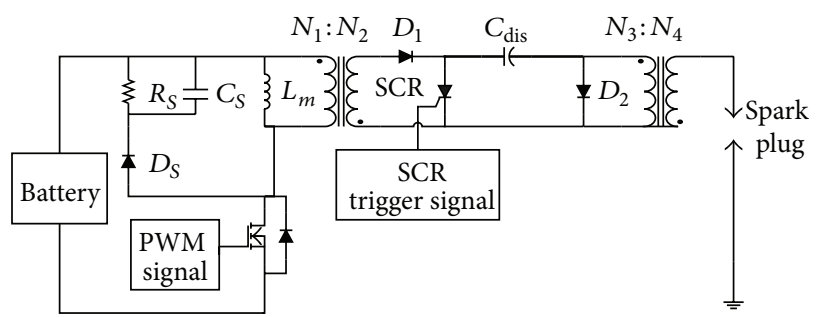

(e)

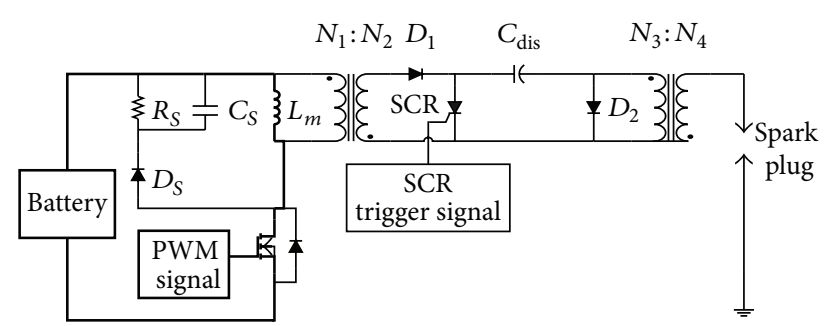

(b)

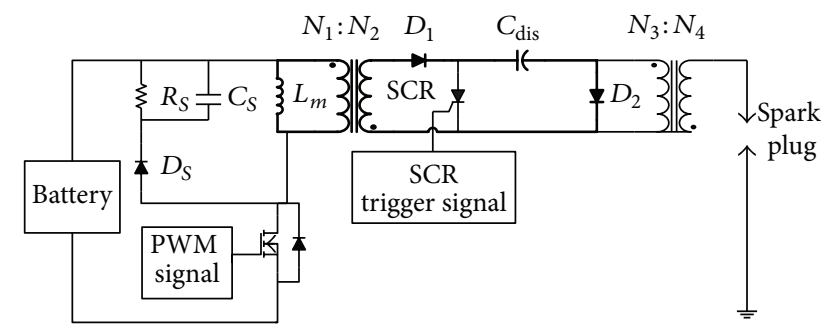

(d)

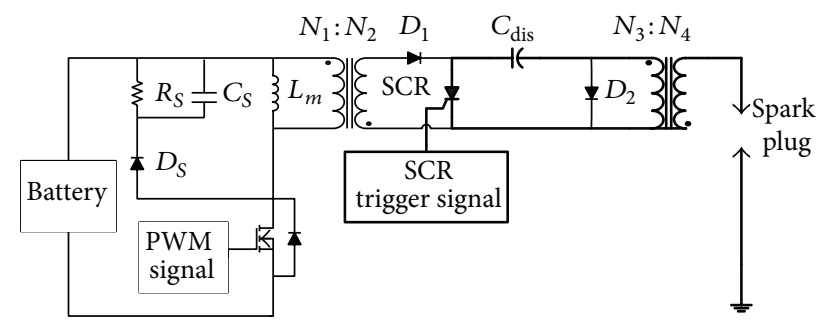

(f)

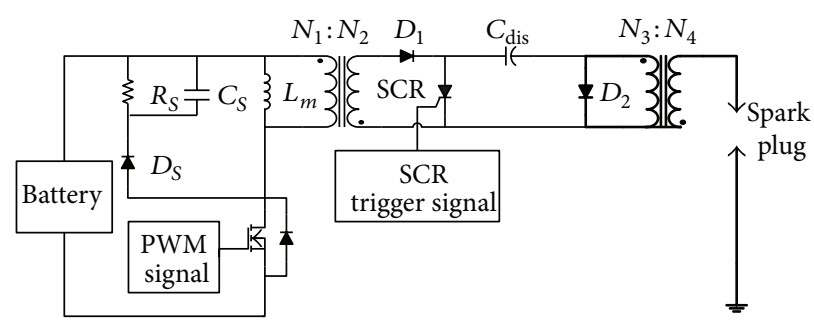

(g)

FiguRE 6: Equivalent circuits for each operation mode over one igniting cycle: (a) mode 1, (b) mode 2, (c) mode 3, (d) mode 4, (e) mode 5 , (f) mode 6, and (g) mode 7.

TABLE 1: Physical exhaust emission comparison between the installations of traditional igniter and proposed igniter.

\begin{tabular}{|c|c|c|c|c|}
\hline \multicolumn{5}{|c|}{ The comparison of exhaust HC and CO for a $125 \mathrm{CC}$ motor at $1500 \mathrm{rpm}$} \\
\hline \multicolumn{2}{|c|}{ Using traditional igniter } & \multicolumn{2}{|c|}{ Using the proposed igniter } & Comparison results \\
\hline \multicolumn{2}{|c|}{ The 1st measurement of exhaust gas } & \multicolumn{2}{|c|}{ The 1st measurement of exhaust gas } & HC: $\frac{187-108}{187} \times 100 \%=42.25 \%$ reduced \\
\hline \multirow{2}{*}{$\begin{array}{l}\mathrm{HC}(\mathrm{ppm}) \\
\mathrm{CO}(\%)\end{array}$} & 181 & $\mathrm{HC}(\mathrm{ppm})$ & 151 & \multirow{2}{*}{ CO: $\frac{1.61-1.30}{1.61} \times 100 \%=19.25 \%$ reduced } \\
\hline & 1.69 & $\mathrm{CO}(\%)$ & 1.52 & \\
\hline \multicolumn{2}{|c|}{ The 2nd measurement of exhaust gas } & \multicolumn{2}{|c|}{ The 2nd measurement of exhaust gas } & HC: $\frac{181-151}{181} \times 100 \%=16.57 \%$ reduced \\
\hline $\mathrm{HC}(\mathrm{ppm})$ & 181 & $\mathrm{HC}(\mathrm{ppm})$ & 151 & $1.69-1.52$ \\
\hline $\mathrm{CO}(\%)$ & 1.69 & $\mathrm{CO}(\%)$ & 1.52 & $00 \%=10.06 \%$ reduced \\
\hline \multicolumn{2}{|c|}{ The 3rd measurement of exhaust gas } & \multicolumn{2}{|c|}{ The 3rd measurement of exhaust gas } & HC: $\frac{196-148}{196} \times 100 \%=24.49 \%$ reduced \\
\hline $\mathrm{HC}(\mathrm{ppm})$ & 196 & $\mathrm{HC}(\mathrm{ppm})$ & 148 & $1.83-1.55$ \\
\hline $\mathrm{CO}(\%)$ & 1.83 & $\mathrm{CO}(\%)$ & 1.55 & 1.83 \\
\hline
\end{tabular}




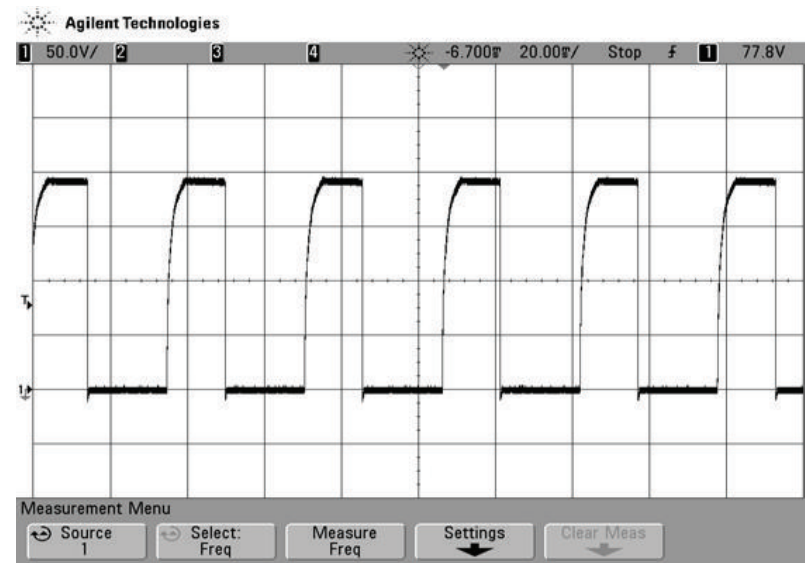

(50 V/div; $20 \mathrm{~ms} /$ div)

FIGURE 7: Experimental result of the voltage waveform across capacitor $C_{\text {dis }}$.

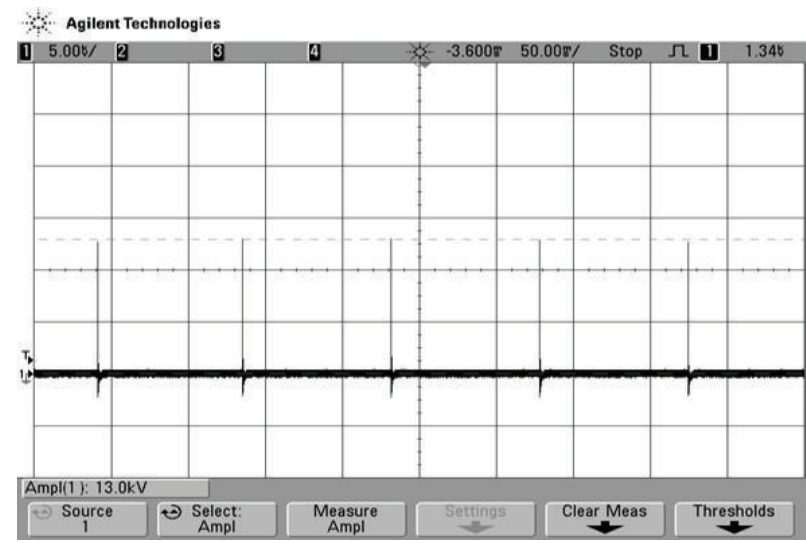

$(5 \mathrm{kV} / \mathrm{div} ; 50 \mathrm{~ms} / \mathrm{div})$

FIGURE 8: The measured voltage waveform supplying to spark plug.

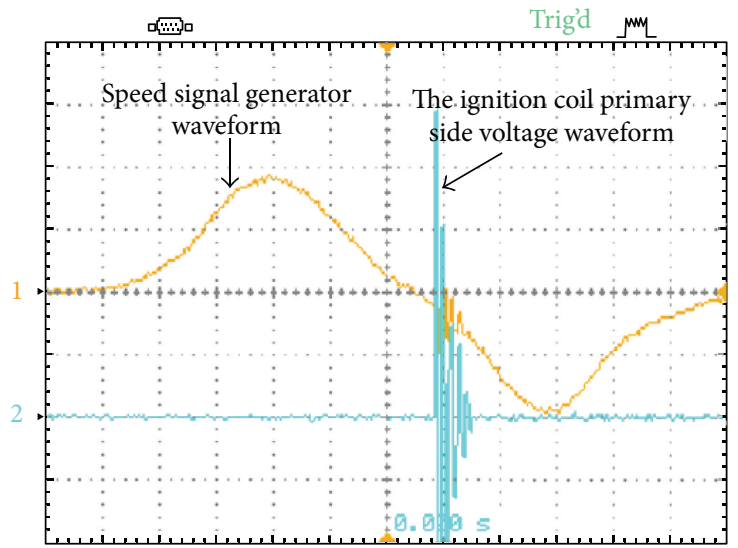

(a)

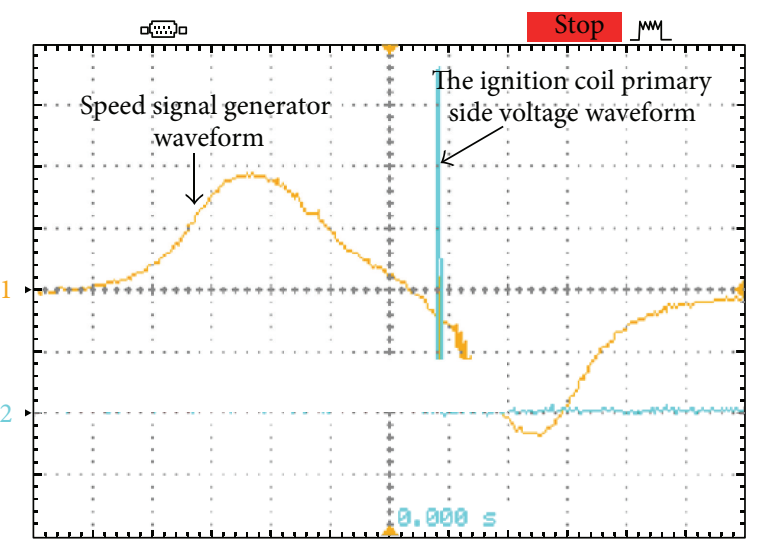

(b)

FIGURE 9: The physical voltage waveforms measured from speed signal generator and ignition coil primary at $1600 \mathrm{rpm}$ : (a) traditional igniter and (b) the proposed igniter. 


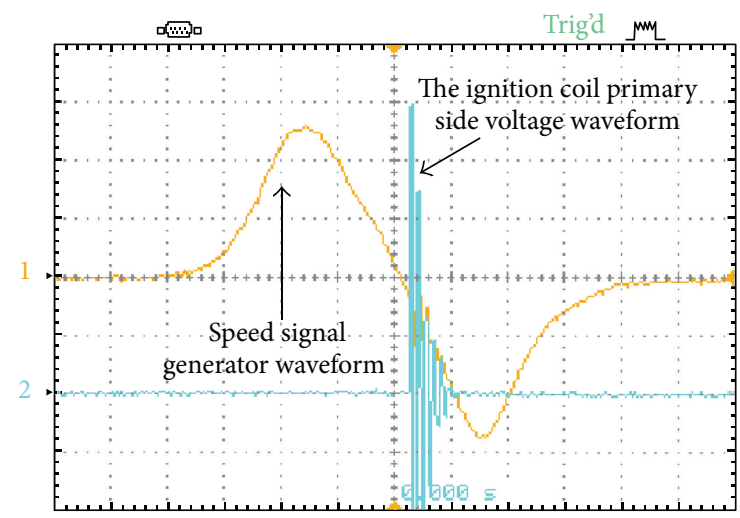

(a)

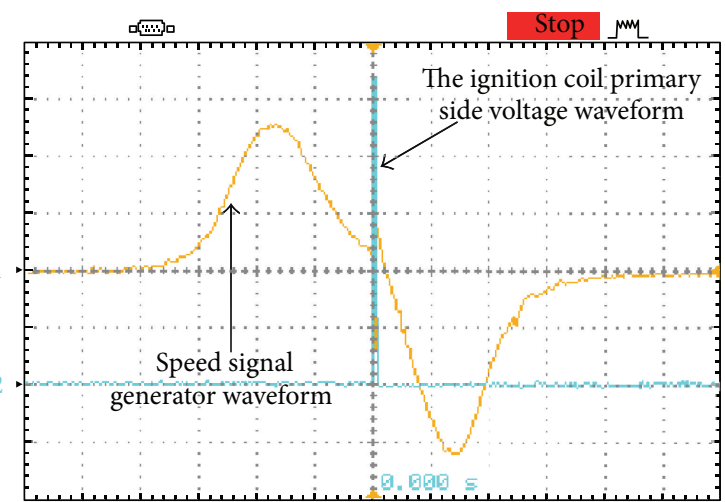

(b)

FIGURE 10: The physical voltage waveforms measured from speed signal generator and ignition coil primary at $2200 \mathrm{rpm}$ : (a) traditional igniter and (b) the proposed igniter.

TABLE 2: Physical fuel consumption comparison between the installations of traditional igniter and proposed igniter.

\begin{tabular}{|c|c|c|c|}
\hline \multicolumn{4}{|c|}{ The physical measurements of fuel consumption from a $125 \mathrm{CC}$ motor } \\
\hline & Mileage $(\mathrm{km})$ & Fuel consumption (liter) & Calculation \\
\hline \multicolumn{4}{|c|}{ With traditional igniter } \\
\hline 1 & $1708-1820$ & 4.43 & \multirow{4}{*}{$\begin{array}{l}\text { Total trip: } 386 \mathrm{~km} \\
\text { Fuel consumption: } 14.88 \text { liters } \\
\text { Average: } 25.94 \mathrm{~km} / \mathrm{liter}\end{array}$} \\
\hline 2 & $1820-1923$ & 3.53 & \\
\hline 3 & $1923-2001$ & 3.53 & \\
\hline 4 & 2001-2094 & 3.39 & \\
\hline \multicolumn{4}{|c|}{ With the proposed igniter } \\
\hline 1 & $2670-2736$ & 3.27 & \multirow{4}{*}{$\begin{array}{l}\text { Total trip: } 280 \mathrm{~km} \\
\text { Fuel consumption: } 9.88 \text { liters } \\
\text { Average: } 28.34 \mathrm{~km} / \text { liter }\end{array}$} \\
\hline 2 & $2736-2861$ & 3.27 & \\
\hline 3 & $2861-2882$ & 1.67 & \\
\hline 4 & $2882-2950$ & 1.67 & \\
\hline & \multirow{2}{*}{\multicolumn{2}{|c|}{ The percentage of fuel saving is $9.252 \%$. }} & $28.34-25.94 \times 100 \%=9.252 \%$ \\
\hline & & & $\begin{array}{ll}25.94 & \times 100 \%=9.252 \% \\
& \text { reduced }\end{array}$ \\
\hline
\end{tabular}

\section{Conflict of Interests}

The authors declare that they have no conflict of interests regarding the publication of this paper.

\section{References}

[1] C. Wangwiwatthana, N. Kaewraungrit, and J. Parnklang, "Gasoline engine multi spark ignition system," in Proceedings of the International Conference on Control, Automation and Systems (ICCAS '07), pp. 1499-1502, October 2007.

[2] A. A. Tropina, L. Lenarduzzi, S. V. Marasov, and A. P. Kuzmenko, "Comparative analysis of engine ignition systems," IEEE Transactions on Plasma Science, vol. 37, no. 12, pp. 2286-2292, 2009.

[3] A. Omar, N. B. Mariun, and I. B. Aris, "Ignition circuit for natural gas ignition system," in Proceedings of the 5th Student Conference on Research and Development (SCORED '07), pp. 16, December 2007.

[4] C.-B. Tzeng, T.-S. Wey, and T.-Y. Su, "Microcomputer based smart engine ignition control system for motorcycles," in Proceedings of the 8th International Conference on Intelligent
Systems Design and Applications (ISDA '08), pp. 215-221, November 2008

[5] F.-J. Zhang, Y.-S. Ge, Y. Huang, F.-S. Liu, Y.-B. Sun, and S.-J. Wu, "A micro-processor based adaptive ignition control system," in Proceedings of the IEEE International Vehicle Electronics Conference (IVEC '99), vol. 1, pp. 34-37, September 1999.

[6] V. J. Thottuvelil and G. C. Verghese, "Analysis and control design of paralleled DC/DC converters with current sharing," IEEE Transactions on Power Electronics, vol. 13, no. 4, pp. 635-644, 1998.

[7] W. A. Tabisz and F.-C. Lee, "DC analysis and design of zerovoltage-switched multi-resonant converters," in Proceedings of the 20th Annual IEEE Power Electronics Specialists Conference (PESC '89), pp. 243-251, June 1989.

[8] R. L. Steigerwald, R. W. De Doncker, and M. H. Kheraluwala, "A comparison of high-power DC-DC soft-switched converter topologies," IEEE Transactions on Industry Applications, vol. 32, no. 5, pp. 1139-1145, 1996.

[9] R. Zane and D. Maksimovic, "Modeling of high-power-factor rectifiers based on switching converters with nonlinear-carrier control," in Proceedings of the 27th Annual IEEE Power Electronics Specialists Conference, vol. 2, pp. 1105-1111, January 1996. 
[10] R. Zane and D. Maksimović, "Nonlinear-carrier control for high-power-factor rectifiers based on up-down switching converters," IEEE Transactions on Power Electronics, vol. 13, no. 2, pp. 213-221, 1998.

[11] R. Erickson, M. Madigan, and S. Singer, "Design of a simple high-power-factor rectifier based on the flyback converter," in Proceedings of the 5th Annual Applied Power Electronics Conference and Exposition (APEC '90), vol. 13, no. 4, pp. 792801, March 1990.

[12] G. Nirgude, R. Tirumala, and N. Mohan, "A new, large-signal average model for single-switch DC-DC converters operating in both CCM and DCM," in Proceedings of the 32nd IEEE Annual Power Electronics Specialists Conference, vol. 3, pp. 1736-1741, June 2001.

[13] P. R. K. Chetty, "Current injected equivalent circuit approach (CIECA) to modeling of switching dc-dc converters," IEEE Transactions on Aerospace and Electronic Systems, vol. 17, no. 6, pp. 802-808, 1981.

[14] G. Hua and F.-C. Lee, "Soft-switching techniques in PWM converters," IEEE Transactions on Industrial Electronics, vol. 42, no. 6, pp. 595-603, 1995.

[15] C.-T. Choi, C.-K. Li, and S.-K. Kok, "Control of an active clamp discontinuous conduction mode flyback converter," in Proceedings of the 3rd IEEE International Conference on Power Electronics and Drive Systems (PEDS '99), pp. 1120-1123, July 1999.

[16] R. Oruganti, P. C. Heng, J. T. K. Guan, and L. A. Choy, "Soft-switched DC/DC converter with PWM control," IEEE Transactions on Power Electronics, vol. 13, no. 1, pp. 102-114, 1998.

[17] C.-T. Choi, C.-K. Li, and S.-K. Kok, "Modeling of an active clamp discontinuous conduction mode flyback converter under variation of operating conditions," in Proceedings of the 3rd IEEE International Conference on Power Electronics and Drive Systems (PEDS '99), pp. 730-733, July 1999.

[18] R. Watson, F.-C. Lee, and G.-C. Hua, "Utilization of an activeclamp circuit to achieve soft switching in flyback converters," IEEE Transactions on Power Electronics, vol. 11, no. 1, pp. 162$169,1996$.

[19] H. Yoshino, K. Sato, A. Tomago, and I. Yamauchi, "Development of a corona discharge detector for flyback transformers," IEEE Transactions on Consumer Electronics, vol. 23, no. 1, pp. 114-119, 1977.

[20] F. Forest, E. Labouré, T. A. Meynard, and J.-J. Huselstein, "Multicell interleaved flyback using intercell transformers," IEEE Transactions on Power Electronics, vol. 22, no. 5, pp. $1662-$ 1671, 2007.

[21] W. Langeslag, R. Pagano, K. Schetters, A. Strijker, and A. van Zoest, "VLSI design and application of a high-voltagecompatible SoC-ASIC in bipolar CMOS/DMOS technology for AC-DC rectifiers," IEEE Transactions on Industrial Electronics, vol. 54, no. 5, pp. 2626-2641, 2007.

[22] N. P. Papanikolaou and E. C. Tatakis, "Minimisation of power losses in PFC flyback converters operating in the continuous conduction mode," IEE Proceedings, vol. 149, no. 4, pp. 283-291, 2002. 


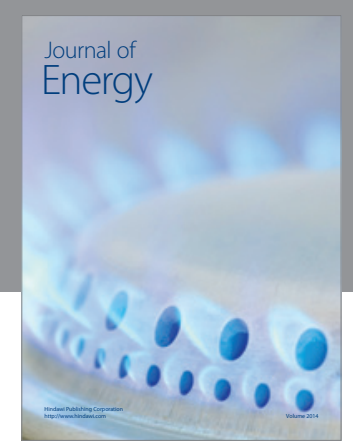

Journal of

Industrial Engineering
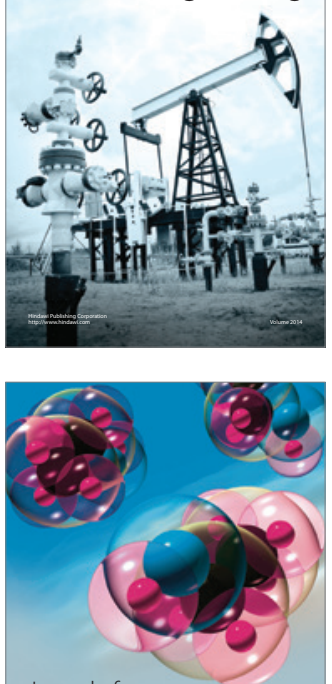

Fuels
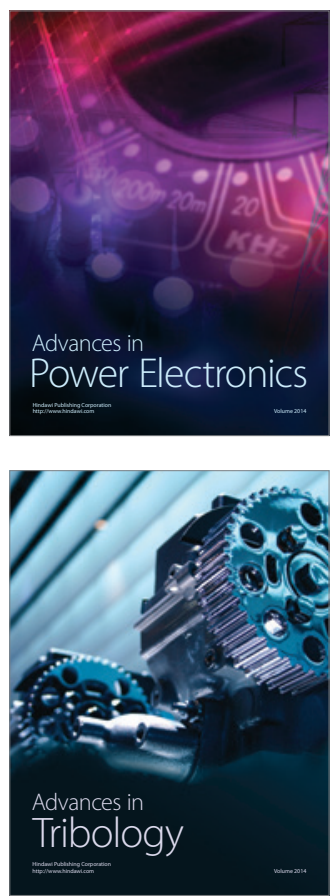

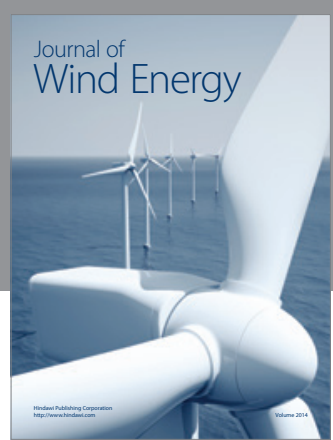

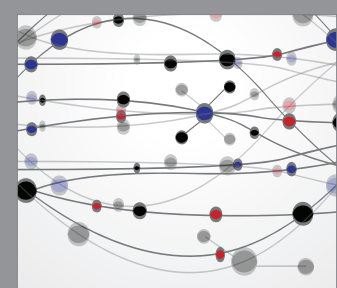

The Scientific World Journal

Submit your manuscripts at http://www.hindawi.com

Journal of

Structures
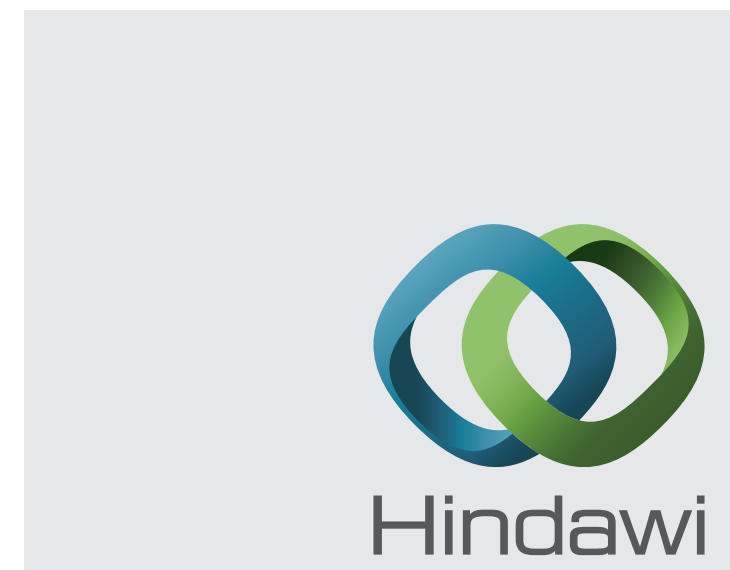

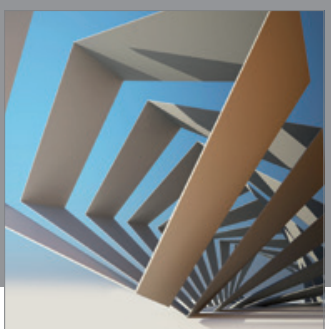

Rotating

Machinery
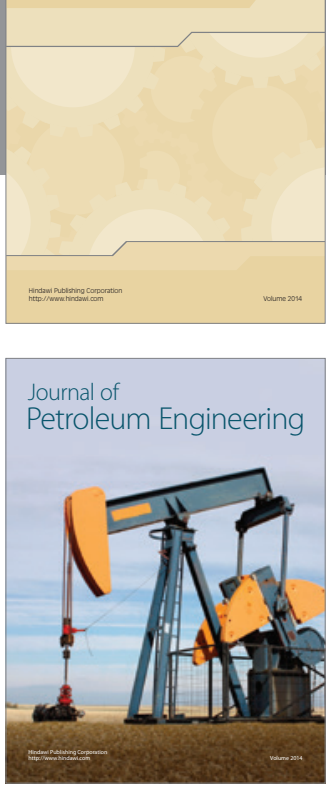

Journal of

Solar Energy
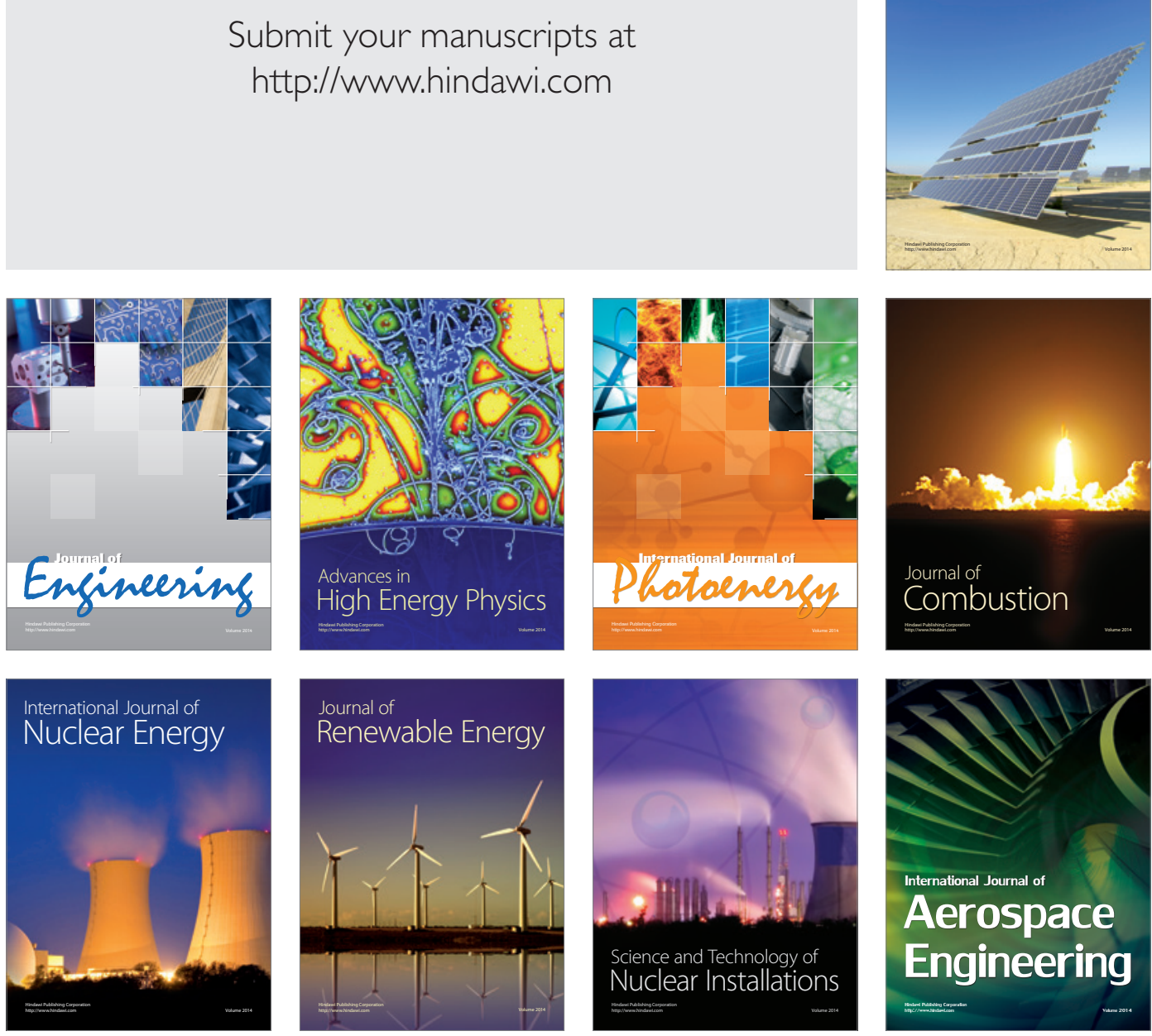